\title{
Acceptance of GST- A Stride for Profitable Fusion of India
}

\author{
Malkeet Singh $^{1}$ and Minal Verma ${ }^{2}$ \\ ${ }^{1 \& 2}$ Assistant Professor, Department of Business Management, \\ Innocent Hearts Group of Institutions, Jalandhar, India.
}

CITATION: Singh, Malkeet and Verma, Minal (2020), “Acceptance of GST- A Stride for Profitable Fusion of India", MERC Global's International Journal of Management, Vol. 8, Issue 2, pp. 60-63.

ARTICLE HISTORY: Submitted: February 15, 2020, Revision received: March 16, 2020, Accepted: March 26, 2020

ARTICLE TYPE: Review paper

\begin{abstract}
The Goods and Service Tax (GST) is the single VAT (Value added tax) which openly affects all goods and services of India. The concept of the GST was introduced on $1^{\text {st }}$ July 2017 with a twin structure which means it will have two components- the Central GST and the State GST. It is designed to create a sole, united bazaar and that will yield corporate profit and the economic unification. GST is expected to simplify tax administration, ensure 'Ease of Doing Business' and support 'Make in India.' It will influence the government's financial health as the tax gathering structure would become clearer, making tax fudging complex. An effort is made in this paper to learn the idea of GST and its blow to the Indian economy. The study also aims at how the unified integrated tax system will bring profitable fusion in India.
\end{abstract}

KEYWORDS: GST, Indirect tax, Profitable fusion, Make in India.

\section{BIBLIOGRAPHY}

1. Ahamad, Ehtisham and Poddar, Satya (2009). "Goods and Service Tax Reforms and Intergovernmental Consideration in India”, Asia Research Center, LSE.

2. Gupta, Nishita (2014), "Goods and Services Tax: Its implementation on Indian economy", International Research Journal of Commerce, Arts and Science, Vol. 5, Issue 3, pp. 126-133

3. John, P. V. (2010), Reforms in Sales Tax Structure: A Study with Special Reference to VAT in Kerala, Unpublished PhD Thesis, Mahatma Gandhi University, Kottayam.

4. Kamna, Pinki Supriya and Verma, Richa (2014), "Good and Service Tax - Panacea For Indirect Tax System In India", Tactful Management Research Journal, Vol. 2, Issue 10, July.

5. Kelkar, Vijay (2009), GST Reduces Manufacturing Cost and Increases Employment, Times of India, October 13.

6. Poddar, Satya and Bagchi, Amaresh (2007), Revenue-neutral rate for GST, The Economic Times, November 15.

7. Rao, Govinda (2014), "Goods and Services Tax in India: Challenges and prospects", Macroeconomic Policy, August 14.

8. Taqvi, Syed Mohd Ali (2013), "Challenges and Opportunities of Goods and Service Tax in India", Indian Journal of Applied Research, Vol. III, Issue V, May.

9. Vasanthagopal, R. (2011), "GST in India: A Big Leap in the Indirect Taxation System", International Journal of Trade, Economics and Finance, Vol. 2, No. 2, pp. 114-146. 